\title{
RE-EVALUATION OF THE PLATINUM SDI: A CRITICAL COMMENTARY
}

\author{
Ernst Drewes* \\ North-West University \\ Ernst.Drewes@nwu.ac.za \\ Ewert Kleynhans\# \\ North-West University \\ Ewert.Kleynhans@nwu.ac.za
}

September 2010

\section{Abstract}

The Platinum Spatial Development Initiative (SDI) in the North West Province was initiated 10 years ago to address the spatial economic development challenges of the region. This revised commentary aims to re-evaluate development, and intends to provide an objective overview of the successes and failures of the Platinum SDI. The aim is to provoke a debate on the matter in order to assess whether or not the Platinum SDI is to the advantage of the economic development of the country and its people, and especially the poor. This paper considers the historical context and evaluates a number of arguments, either in support of or questioning the viability of the Platinum SDI. The paper concludes that after more than a decade there is still little evidence that the Platinum SDI will in the near future be efficient. At present, the Platinum SDI has very little to offer. To succeed will require more effort by all concerned, and especially much more commitment from the relevant governmental structures.

\section{Keywords}

Economic development, economic geography, spatial development, SDI, industrial development, policy

\footnotetext{
* Dr Ernst Drewes is a senior lecturer in Urban and Regional Planning at the School of Environmental Sciences and Development at Potchefstroom Campus of North-West University, South Africa.

\# Prof Ewert Kleynhans is an associate professor in the School of Economics at Potchefstroom Campus of North-West University, South Africa.
} 


\section{INTRODUCTION}

The Platinum Spatial Development Initiative (SDI) in the North West Province was initiated a little more than 10 years ago. In 2003, Development Southern Africa published an evaluation of this SDI (by Kleynhans, Naudé \& Van der Merwe, 2003). Some of the authors were advisors to the provincial government and instead of providing a scientific evaluation; the article seemed to put the provincial authorities on a pedestal. That article refrained from negative commentary and seemed biased. This "commentary" wishes to re-evaluate development since the previous publication; it intends to set the record straight and aims to provide an objective overview on the successes and failures of the Platinum SDI. This is a minority report of a sort, but also an evaluation of the five years following the previous evaluation. The objective is to activate a vigorous debate on the matter in order to attract renewed attention to SDIs and facilitate their success.

The Platinum SDI was identified during 1996 by the Department of Trade and Industry in collaboration with the Department of Transport to advance development in the North West Province. The principal objective was the general stimulation of economic development in the North West Province. This entails government initiating economic activities in collaboration with the private sector, which could lead to economic growth, job creation and eventually to the alleviation of poverty in the province.

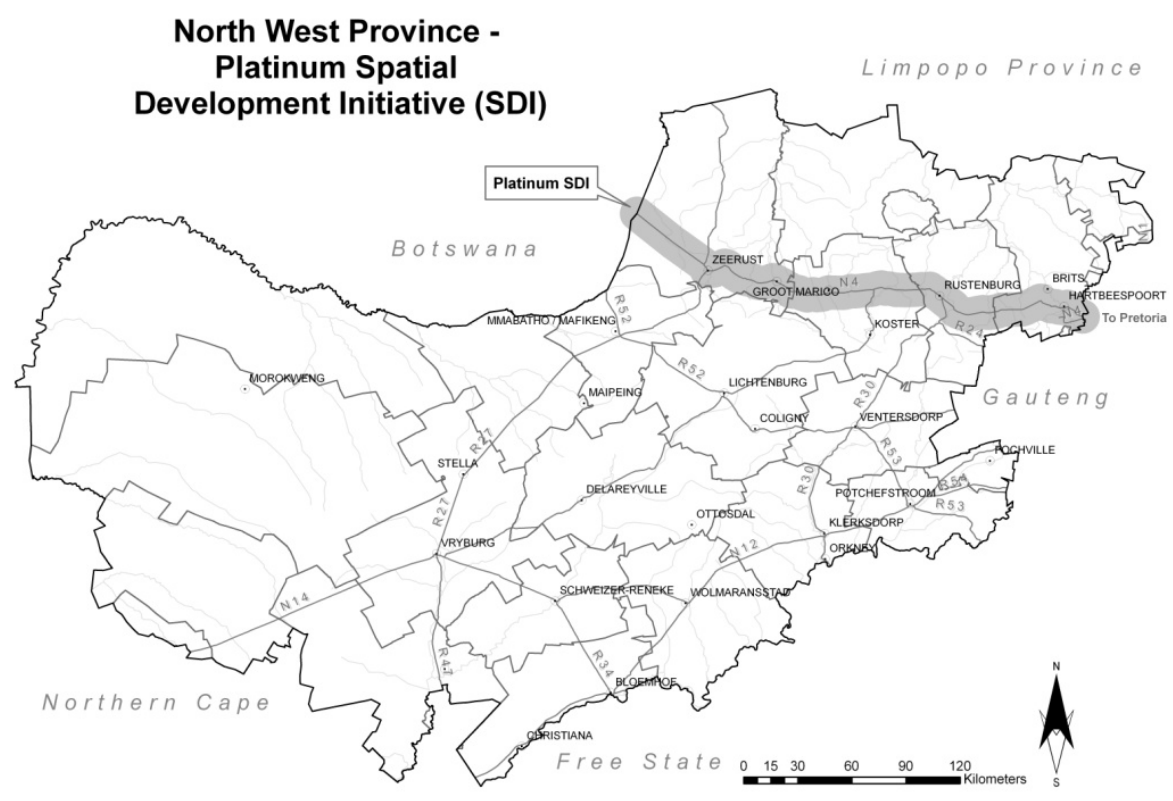

\section{Map 1: $\quad$ North West Province: Location of the Platinum SDI}

Source: Maxim Planning Solutions, 2004 
The Platinum SDI is a development belt along the N4 Highway in the North West Province of South Africa, between Gauteng and Lobatse in Botswana (see Map 1). It is the central section of the Coast-2-Coast SDI, which centres on a trans-continental highway across Southern Africa, stretching from Maputo harbour in Mozambique to Walvis Bay in Namibia (see Map 2). The concept is to develop an approximately $50 \mathrm{~km}$ stretch of land both sides of the road in order to attract industrial development and associated investments to the SDI, which could have many forward and backward linkages with other firms and areas in the province and promote further development and employment due to the linkage and other spill-over effects.

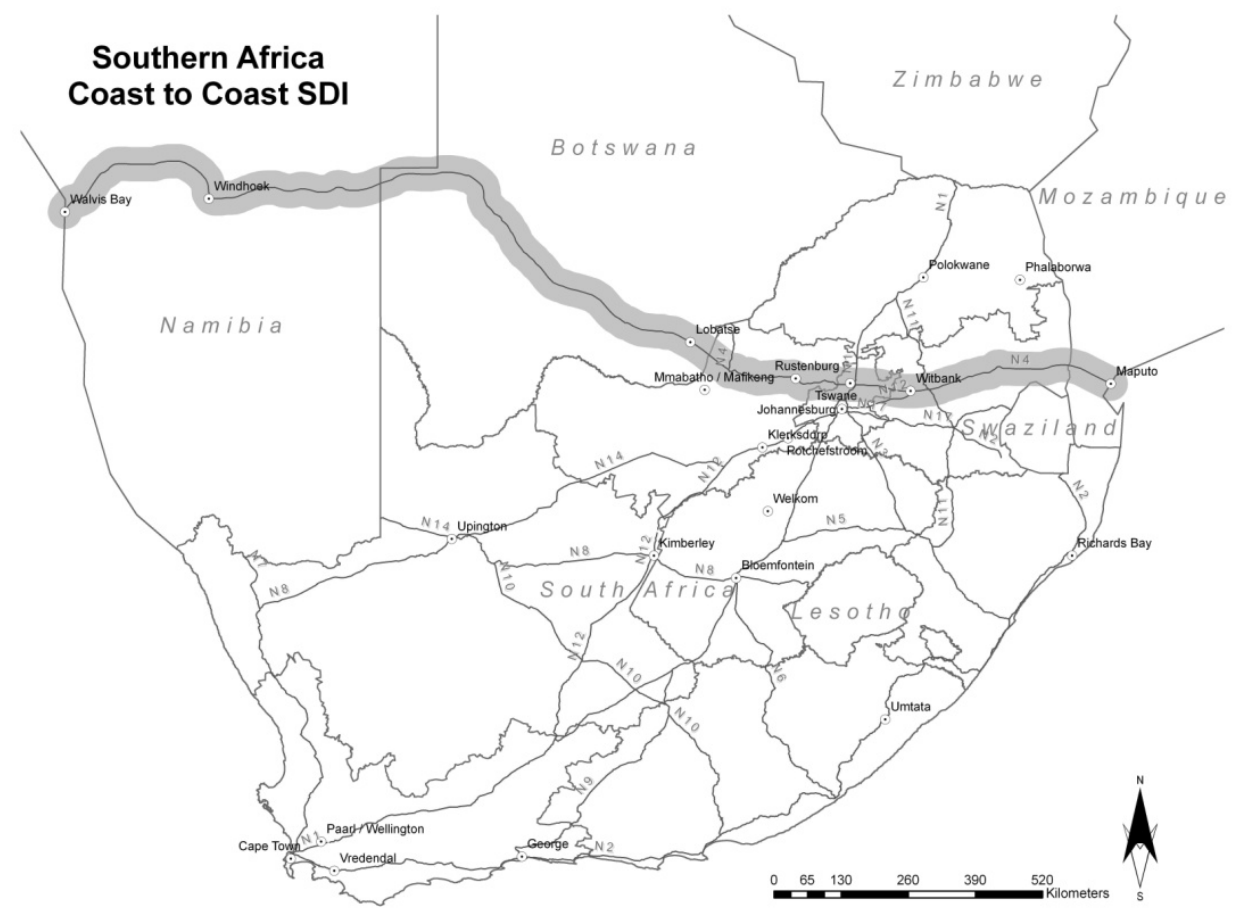

\section{Map 2: The Coast-2-Coast SDI}

Source: Maxim Planning Solutions, 2004

Initially, the SDIs were regarded as a priority by central government. Several research programmes were commissioned and significant amounts of money were invested in these programmes. Research on the Platinum SDI was financed by the Development Bank of Southern Africa, and the Industrial Development Corporation (IDC) ensured quality control. The Platinum Consortium (see Kleynhans et al., 2003:626) identified approximately 50 potential industrial projects that were economically viable. A further 130 tourism ventures with potential were identified by the Tourism Research Group, an Agricultural Team studied four projects, and approximately 30 investment opportunities were identified in the mining industry.

By the turn of the century, the responsibility of the SDIs was transferred to the provincial governments, who emphasised their commitment to the success of these SDIs (Morule, 2001:12). In the meantime, Mmabatho (Mafikeng) was declared an Industrial Development Zone (IDZ), and some new industries settled there. In retrospect, it would seem that the plans have borne 
little fruit over the past 10 years, since little significant developmental impact is visible within the identified SDI and IDZ. The accusation of Africa being a basket case, where no amount of money and effort will ever lead to development (Morule, 2001:12), must be considered in this context. The Platinum SDI still seems to be little more than an impossible dream.

This paper will begin by considering the historical context, and it will then evaluate a number of arguments, either in support of or questioning the viability of the Platinum SDI. Consideration will also be given to the import substitution programme, which was eventually supplanted by an export-promotion policy, followed by the development of regional industrial policy in South Africa. Finally, new developments in the Platinum SDI will be accounted for and the viability of the Platinum SDI evaluated.

\section{HISTORICAL OVERVIEW}

The previous article on this topic (Kleynhans et al., 2003:618) implied that the RIDP, decentralisation policies and RDP caused underdevelopment and poverty in the region. These policies were, however, merely designed to rectify the problems that already existed. The SDI programme envisaged a normalisation of the space economy, especially with port cities. Although SDIs were never about decentralisation, the Regional Industrial Development Programme (RIDP, 1991) paved the way for SDI initiatives and the Reconstruction and Development Programme (RDP), as both were supposed to be built on pure "economic principles".

It seems that the authorities managing both the RIDP (1991) and the SDIs neglected their responsibility to create employment for the people, because of the failure of decentralisation. It was the intention of previous policies to create jobs where people lived, but instead people still migrated to larger locations where they thought the opportunities were better. That led to policies, like the RIDP (1991), to determine where economic potential was, regardless of the availability of labour. Job opportunities were no longer taken to the people; instead, the assumption was made that people will migrate to areas where opportunities exist (Le Roux, 1996:3). This enabled the authorities to exploit investment opportunities and growth poles on pure economic principles.

The following section will firstly attend to the policy of import substitution industrialisation and then to the Regional Industrial Development Programme. These were important historic policies that were supposed to help shape the South African space economy and were aimed at regional economic development through industrial development.

\subsection{Import Substitution Programme}

Since the 1920s, South Africa has applied a strategy of import substitution to develop the industrial sector. Tariffs and quotas protected industries, which produced final manufactured goods. Industries that delivered intermediary goods enjoyed less protection, while industries that produced capital goods had very low levels of protection (Suleman, 1998:83).

At the start of the 1970s, the South African authorities realised that an outward-looking policy aimed at exports promotion would lead to higher economic welfare. This led to exportpromoting incentives in 1972, which included a rebate on imported inputs used in the production of export commodities, tax concessions, compensation for financing costs, consumption of 
electricity and costs of airfreight, as well as subsidies for foreign market expenses, in the form of tax allowances.

Although the outward-orientated trade policy is in line with the best international practices, it might exaggerate spatial inequality in South Africa, because tariff liberalisation might favour industries that had already settled in metropolitan areas (Coetzee et al., 1997:187). On the other hand, a "normalised" policy that promotes export can also benefit industries, especially those close to the coast or export ports, as the focus moved away from domestic markets to export markets.

Following an import substitution policy, saturation of local market demand was soon reached at a ceiling that cannot increase. Export-orientated policies, on the other hand, can always find new markets. Export-orientated policies also align local cost structures to international prices, while import substitution attempts to align international prices to local price distortions, which is not possible for small, less developed economies.

Due to the sanctions campaign, the country was, however, forced to continue its previous policy of import substitution. In 1983, the Kleu commission was appointed to investigate the industrial development strategy in South Africa. On the advice of the Kleu commission, a surcharge of between 10 and 60 per cent was introduced in 1985, especially on luxuries (Suleman, 1998:85). In 1987, the Board of Trade and Industry suggested a Structural Adjustment programme to promote exports. The programme was, however, too complex and in 1990 it was replaced by the General Export Incentive Scheme (GEIS) (Belli et al., 1993:24). The main principle of this scheme was to subsidise exports in relation to the amount of value added in South Africa.

Since the new political dispensation in 1994, South Africa has been increasingly exposed to the international arena. South Africa signed the General Agreement on Trade and Tariffs in Marrakech in 1995, according to which quotas on imports and the general level of tariffs were to be reduced. South Africa is now a member of the World Trade Organisation (WTO), which monitors these agreements. Import substitution was gradually replaced by a policy of export promotion. Trade and industrial reform was also one of the main elements of the GEAR strategy on the supply side (GEAR, 1996). This includes greater privatisation, the reduction of tariff protection and the phasing out of currency exchange control measures (Naudé, 1997:71). For the development of the different regions in the country, it meant that incentives had to be reconsidered and that infrastructure aimed at exports in particular had to receive more attention. This is also in line with the Accelerated and Shared Growth-South Africa (ASGISA) programme adopted by the government in 2006 .

The following section focuses on regional industrial development in South Africa.

\subsection{Regional Industrial Development}

It is essential to optimise a country or region's resources in the spatial context and to encourage well-balanced spatial economic development policies (Armstrong \& Taylor, 2001). If the decentralisation policy of 1960 had been successful, it would have improved people's living conditions and welfare, especially in the rural areas, and at the same time proved that the government's homeland policy under apartheid had the ability to benefit everyone. However, it was inefficient and had to be replaced by the 1982 Regional Industrial Development Programme (RIDP).

This 1982 RIDP policy included all sectors, but emphasised industrial development (Drewes, 
2009:101). The most important short-term incentives to encourage regional industrial development were subsidies for job creation and labour expenses, interest rates, relocation and unforeseen expenses. Long-term incentives included housing subsidies, cash training allowances, subsidies on electricity, transport rebates on all goods leaving the country and tender preferences of up to 10 per cent on all tenders to state departments, as well as some public corporations and local authorities.

The intention of the 1982 RIDP was to emphasise economic considerations (Drewes \& Bos, 1995:268; Bos, 1997:304) and to encourage private initiatives to assist higher economic development. During 1985, a productivity support scheme was introduced that paid consultation fees in full. However, the RIDP policy could not achieve sustained development and job creation in the decentralised areas despite the high expenditure. The migration to towns, cities and metropolitan areas could not be curbed either (Drewes \& Bos, 1995:268; Le Roux, 1996:2).

This led to the acceptance of a new RIDP in 1991. Both these RIDP programmes were said to be built on "pure economic principles", but it should be kept in mind that these policies were, in the first place, the product of the racial political policies of the time and not aimed at economic efficiency. The 1991 RIDP shifted from the development of artificial growth poles with limited potential towards an approach where natural potential and market forces enjoyed precedence. It was, however, claimed that pure economic criteria were now accepted as the norm in place of political idealism. The way towards true economic development was now open, and the Reconstruction and Development Programme (RDP) was initiated in 1995, with the "Growth, Employment and Redistribution" strategy (GEAR) being accepted in 1996. These were both policies that were deemed to stimulate natural development.

According to Le Roux (1996:8), the principles of the new RIDP were:

- The provision of regional development, with the emphasis on fewer developed regions, in order to enhance the performance of the South African economy;

- The development of an integrated South African spatial economy that would consist of a number of broadly defined development areas;

- A market-orientated development approach;

- Free mobility of the factors of production;

- A multi-sector development approach, backed by regional development strategies and based on comparative costs and advantages; as well as

- A market-orientated profit-output-based incentive scheme.

The 1991 RIDP also promoted relatively well-established coastal and rural areas that were excluded by the previous policy, but that could offer competitive advantages to investors. This new programme moved away from a system where investors were compensated for locational disadvantages, towards incentives that were based on the economic and financial performance of enterprises. The objective was to utilise natural competitive advantages of regions, to lead investors to investment decisions based on pure economic principles that were aimed at sustaining economic growth (Le Roux, 1996:11). The 1991 RIDP, in conjunction with the National Regional Development Policy, attempted to develop the whole country, including all regions and sectors. The RIDP policy could not, however, achieve sustained development and job creation in the decentralised areas, nor could it stop the migration to towns, cities and metropolitan areas (Drewes \& Bos, 1995:268; Le Roux, 1996:2; Drewes, 2009:105). This underlines the fact that the 
1991 RIDP policy was a continuation of the previous policies and, although it was adapted, it was essentially still based on the political dispensation of that time. The RIDP was also criticised for its inability to create employment. Furthermore, it did not lead to significant economic growth and was not cost efficient (Ligthelm \& Wilsenach, 1993:377).

In conjunction with the above, the policy of Spatial Development Initiatives (SDIs) was accepted in 1996 to address the fragmented development patterns of the past, and to promote equity, integration and efficiency (Drewes, 2009:113). The SDI methodology recognised labour as a mobile factor of production and attempted to rationalise location decisions. Developmental regions, axes and projects identified by their inherent under-utilised economic potential aimed at sustainable employment creation in these regions by identifying and facilitating new investment opportunities. Private and public investments are stimulated through infrastructure, manufacturing, mining, small business (SMME), tourism, agriculture, housing and the provision of water in certain areas to achieve the advantages of agglomeration (Wiese, 1996:3). The SDIs, the GEAR and current ASGISA strategies supplement faster economic growth and the stabilisation of the economy. They unlock economic opportunities, stimulate employment and raise the prospects of previously disadvantaged sectors of the community (DOT, 1997:60).

The general development objectives of the RDP, GEAR and ASGISA were the transformation of the South African economy into a sustainable, fast-growing, internationally competitive, labourabsorbing, and outward-orientated economy. To achieve this, the government developed an industrial policy that supports local manufacturing (DTI, 1998:1). Current industrial policies are focused on the development of internationally competitive industries and clusters with an emphasis on job creation. This implies a movement away from demand-side interference towards supply-side supporting criteria, which are developed to decrease unit costs and speed up advancement in adding value, as envisaged by the ASGISA programme.

The next section indicates the potential of the North West Province and development that followed the introduction of the Platinum SDI.

\subsection{Industrial Development in the North West Province}

The Platinum Spatial Development Initiative (SDI) was identified and officially launched in 1996. The Platinum SDI includes the area between Pretoria and Rustenburg, as well as to the west of Zeerust up to the border with Botswana, and provides a link between the harbours of Maputo Port in Mozambique and Walvis Bay in Namibia. The N4 toll road between Pretoria and Botswana was chosen as the anchor project. The Platinum SDI also connects the capital cities of four SADC countries, namely Maputo (Mozambique), Pretoria (South Africa), Gaborone (Botswana) and Windhoek (Namibia).

Mafikeng was identified as an Industrial Development Zone (IDZ) due to its location close to the Lobatse airport, which should lead to increased traffic on this corridor. It was further envisaged that the increased traffic would lead to the upgrading of infrastructure, both between Mafikeng and Lobatse and Mafikeng and Walvis Bay. The IDZ is similar to the old Export Processing Zones $(\varepsilon P Z s)$, without the negative aspects associated with the latter. The Mafikeng airport can, for instance, serve as a dry dock, being the second largest airport in Southern Africa, with regard to the size of aircraft it can handle and volume of traffic. It was indicated that the Mafikeng IDZ could boost the economies of scale of both road and rail transport infrastructure and could lead to higher provincial exports (Kleynhans et al., 2003:624).

The Platinum SDI was highlighted as a province with great industrial development potential, 
highlighting linkages, clusters and the competitiveness of industries in the North West Province, with the ability to attract local and international investments (Kleynhans et al., 2003:625; Drewes, 2009:112). It also stated that the province has the potential to become one of South Africa's prime tourist destinations. Mention was furthermore made of rural development and the development strategy for the small business sector, as well as the establishment of a provincial investment promotion agency, known as "Invest North West" at the end of 2000, which illustrated the provincial government's support of the SMME sector and direct foreign investment.

By 2006, the N4 road along the Platinum SDI was built, the toll roads were functioning and the Mafikeng Industrial Development Zone (Pty) Ltd Company (MIDZ) was established. At the Mafikeng IDZ, a large shopping centre was built and the construction of the first dedicated nursery aimed at supplying saplings of oil-bearing trees to produce Bio-Diesel at Setumo Dam was initiated by the MIDZ. The project includes the potential development of an industrial node that will offer investment opportunities for commercial activities. The MIDZ appointed a project management firm, which would manage a portfolio of infrastructure projects, which included roads, water and electrification (Anon, 2006).

There were great differences between the national and provincial governments' interpretation and implementation of the SDI programme. This has been one of the factors that have contributed to the failure of the Platinum SDI thus far. The impression gained is that the provincial authorities regard the building of the road and the establishment of the MIDZ as the conclusion of the Platinum SDI.

The following section evaluates the viability of the Platinum SDI.

\section{VIABILITY OF THE PLATINUM SDI}

In this section, the various arguments concerning the viability of the Platinum SDI are evaluated. Previously, the potential of the development axis principle and the positive aspects of the growth poles in the Platinum SDI were evaluated, as well as the progress made by the provincial government concerning the coordination and cooperation by the authorities, and an overview on anchor projects and the multi-sector approach (Kleynhans et al., 2003:627). There were, however, aspects regarding the Platinum SDI that did not receive sufficient treatment at that time, and these will be updated in the following sections.

\subsection{Policy objectives}

The 1982 RIDP aimed to provide employment near people's homes, taking jobs to the people (Le Roux, 1996:8). As large-scale unemployment and poverty are prevalent in remote areas, creating opportunities in those regions would be ideal. The rationale behind the 1960 decentralisation policy was also to create border industries near the homelands where most people stayed, in order to curb migrant labour and to support family life (Van Jaarsveld \& Scholtz, 1966:124). This was also the objective of the homeland policy, and success in this regard would serve as justification for apartheid policies.

The RIDP policy was inefficient, however. People still migrated to the areas with the highest economic potential, and this led to the introduction of the 1991 RIDP, which created employment and other opportunities where economic potential existed, disregarding the labour 
potential - as people would migrate automatically. Naudé and Krugell (2003:177) imply that rural development is inefficient and that the focus should not be on the development of rural areas with little economic potential, but on the development of larger South African cities.

With the establishment of the SDIs in 1996, the objective moved back to the earlier policies of 1960 and 1982 (Drewes, 2009:111). Although the SDI programme envisaged labour as a mobile factor of production and believed that industrial location decisions should not be based on market-distorting incentives in pursuit of an political objective, its aim was, once again, to ensure balanced development throughout the province - with all the associated linkage benefits.

The rationale for the Platinum SDI was, however, also based on the dense clustering of the mineral resources and the potential it, in combination with infrastructure investments, offered for economic diversification. Natural-resource-based SDIs, and particularly mineral-based SDIs, are obviously constrained by the immovability of mineral resources. The challenge in cases like the Platinum SDI is to broaden and deepen the development impact based on the significant investment potential of the region.

\subsection{Similarities with previous strategies}

It may be asserted that there are several analogues between the policy of Spatial Development Initiatives and the old RIDPs. The earlier policy of decentralisation has now been replaced by SDIs with many similarities. The RIDPs of 1982 and 1991 aimed at industrial development on purely economic grounds; but in fact, they served racial political ideals. SDIs are now also ostensibly conducted on purely economic principles. However, it is not clear how it will be ensured that other political motives will not be served again. In previous years, decentralisation nodes like Mmabatho, Sun City and areas west of Pretoria were developed, while development centres are now being developed at Mafikeng, Pilanesberg and Rustenburg - which are essentially the same places. In the past, growth poles were developed, for example at Mmabatho. Today industrial development zones (IDZ) are being developed at places like Mafikeng. Attempts were made in the past to curb urbanisation through a policy of decentralisation. Today this is pursued through Rural Development and Local Economic Development (LED). Development axes are now replaced by Spatial Development Initiatives (SDIs), which have a broad spatial meaning, but in effect this also comes down to development along an axis or a road, with the intention of starting development in a region. Previous policy programmes developed the road between Mmabatho and Pretoria as a development axis: today development along the Platinum SDI is the target. It sounds like a game of words. The same places and similar policies are developed, while being called something different. The focus should be on sound policy, giving direction and leading towards development.

Previously, manufactured metal products, basic metals, food processing and chemicals were the largest industries in the former Western Transvaal (mining excluded). These industries experienced the highest growth during the decentralisation policy. Today the same industries are identified as industries that possess comparative advantage and that should be extended as industrial clusters.

It seems that history is repeating itself. Some assert that the policy of decentralisation had not worked in the past and therefore question the viability of developments along the $\mathrm{N} 4$ highway in the North West Province. However, it could be that the previous policies were so effective that industries that had comparative advantages grew to become the largest industries in the region. 
SDI policies differ, however, in the sense that they are outward-orientated, aimed at the supply and demand of commodities in which South Africa has a comparative advantage. Businesses, which have large backward and forward linkages, are encouraged in order for more industries to develop in a centripetal action and create more employment.

The identification of possible clusters also plays an important role in the development of SDIs. In the past, government was accused of establishing industries in the homelands without supplying the necessary infrastructure (Drewes, 2009:105). However, projects are now developed wherever potential exists and the authorities ensure that the necessary infrastructure is provided and developed.

Furthermore, the fact that Bophuthatswana no longer exists provides some important definition and potential to the Platinum SDI. The proximity of two governments along an artificial boundary that was created for ideological reasons was inevitably a dissipation of energies, with Bophuthatswana pulling northwards and the old Western Transvaal pulling southwards. As that divergence no longer exists, this should now contribute towards the natural development of what is, in both the South and Southern African context, a sustainable transport axis with notable assets to industry, minerals and tourism.

\subsection{The Development Axis Growth Points}

A dilemma of the Platinum SDI is that the development axis principle requires a high volume of traffic between the growth points (Geyer, 1998:3). The Platinum SDI has a development growth point in the area of Rustenburg and Pretoria, with the other end running through to Walvis Bay (or seemingly disappearing somewhere in the desert). The idea is, however, to develop many strategically chosen industries, mining, agriculture and tourism destinations along the Platinum SDI and surrounding districts to increase traffic and linkages. The declaration of Mafikeng as an IDZ near the other end of the Platinum SDI does provide a second growth pole, but traffic in that vicinity has not increased significantly.

The idea is also to use the North West Province as a thoroughfare and entrance point to Africa, assuming that traffic volumes along the SDI will increase as trade in the SADC countries and elsewhere rises. Since 2001, traffic on this road has increased annually by one third. Economic development in Botswana is also expanding. The Platinum and Trans-Kalahari corridors are becoming part of the regional canvas and the shorter route to Namibia is already starting to have a detrimental effect on the local economy of Upington. Hence, the corridor is beginning to function and, in tandem, the SDI might begin to follow.

The RIDPs were criticised for the lack of concentration due to large numbers of growth points that were developed (Drewes \& Bos, 1995:268). The large numbers of projects of the SDIs are, however, regarded as a point of strength (Kleynhans et al., 2003:627). The difference might lie in the fact that no artificial growth points are developed, implying that development will not necessarily be stimulated at any point where the necessary economic growth potential does potentially exist. The SDI is also different in its striving towards development in various sectors, and not only one sector, as was the case in some of the previous policies and strategies.

The insufficient number of anchor projects and the multi-sectoral approach of SDIs were adequately dealt with in the earlier article by Kleynhans et al. (2003) and will not be duplicated here. 


\subsection{Incentives}

Incentives for investors are now fewer than in the past, which implies that entrepreneurs would have to be absolutely certain that their resources were allocated optimally in order to gain efficient profits and to reach Pareto optimal welfare for the community. The lack of incentives is advantageous, as incentives can distort the free market mechanism. At national level, the most important remaining incentives are the Manufacturing Development Programme (MDP), the Small and Medium Manufacturing Development programme (SMMDP) for new businesses with assets of up to R3 million and a tax holiday of up to six years. The tax holiday is determined by the type of industry, the location and the share of labour remuneration to value added (Hirsch \& Hanival, 1998:27), grants by the Department of Trade and Industry and export incentives.

From the aforementioned survey, it is evident that several manufacturers are antagonistic towards SDIs, as they increased their cost outlay, especially along the N4 toll road (Kleynhans \& Drewes, 2008b:6). There were substantial increases in the costs of raw materials and other supplies, and the operation of tollgates increased the transport costs of firms. In several instances, firms now pay to use roads that were there in the past and that were built with their taxes. Producers feel that the tollgates also negatively affect business and would like tollgate tariffs to decline.

Some manufacturers indicated, however, that SDIs should make secondary industries more attractive to investors, but the costs of the connecting routes on the N4 are pushing possible investors away. Poor communication from government and their agencies is evident and this should be reversed by well-planned information campaigns from government in order to inform the public and improve the image of government (Kleynhans \& Drewes, 2008a:148).

Very few manufacturers are aware of SDI developments in their vicinity, highlighting possible inefficiencies in the government's communication network in the country (Kleynhans \& Drewes, 2008b:7). Firms feel that the government should provide all kinds of subsidies, aid, incentives, loans and other support, including managerial skills and investment support, if it is sincere in its effort to stimulate industrial development, economic growth and job creation. Currently, respondents indicate that such assistance is lacking (Kleynhans, 2003:256). With the General Agreements on Tariffs and Trade (GATT) and stipulations of the World Trade Organisation (WTO), this is a major problem and to some extent unfair criticism, but manufacturers feel that government has to assist in levelling the playing field (Kleynhans, 2003:328).

The abundance of incentives previously enjoyed does not exist anymore and this reduces the number of potential investors. Some economists believe that it was only the incentives like GEIS and those of the RIDPs that made those past projects profitable, while very little true profits were realised (Drewes \& Bos, 1995:268; see also Hirsch \& Hanival, 1998:38; Batchelor, 1998:2; Dunne et al., 1998:12). Incentives should be a well-designed set of advantages, chosen in such a way that they would attract direct foreign investments efficiently, without distorting local economic development. The rising tax burden that accompanies this also deserves attention as it adds a cost burden to the welfare of the community, which is supposed to benefit from the proposed investments, as everyone is paying taxes directly or indirectly. The location of the Platinum SDI in the regional scheme of transport movements does, however, provide the SDI with some competitive advantage, regardless of any incentives. 


\subsection{Coordination by the authorities}

It is alarming that key projects in the SDIs are identified with little consideration of the other SDIs. Mafikeng airport is, for instance, being developed as a dry dock, while the same is intended at Johannesburg's OR Tambo Airport, Bloemcom and Fickscon in the Free State (Ryan, 1998:38 \& Horn, 1998:40). The same can be said about leather products, motor vehicle components, citrus products, steel and several other industries.

The Coast-2-Coast SDI was initiated to coordinate all the development initiatives between Maputo and Walvis Bay. It is important that such coordination should also consider other SDIs. In some instances, it could lead to problems. Developments at the harbours of Maputo, Richards Bay and Durban, for instance, all focus on the same markets, like Gauteng. Some coordination is essential.

There seems to be a lack of capacity, readiness and motivation from the North West Government to exploit the opportunities of the Platinum SDI optimally (Kleynhans et al., 1998:11). The way in which the Mpumalanga Province employs institutional means to maximise the advantages of the Maputo Development Corridor can be used as an illustration of how it can be done (see Ryan, 1998:30). Fundamental to the future success of the Platinum SDI is the institutional capacity of the North West Province in particular to take advantage of the opportunities the SDI presents. This capacity currently seems lacking. The provincial administration could, for example, allocate specific personnel to the development of the SDI, set up tender procedures, launch demonstration and pilot projects, provide financing, organise investor conferences, and disseminate information to potential investors. The development companies, Invest North West (INW) and the North West Development Corporation, were established, which were steps in the right direction.

\subsection{Empirical results}

When considering the results of the Platinum SDI initiative, after 10 years, it is not easy to find anything that indicates higher development within this SDI (Kleynhans, 2009:19). There was growth in investment and job creation, but it is not higher than it would have been without an SDI, and it does not differ significantly from the rest of the province.

TABLE 1: Human Development Index

\begin{tabular}{lllllllllll}
\hline HDI & 1996 & 1997 & 1998 & 1999 & 2000 & 2001 & 2002 & 2003 & 2004 & 2005 \\
Platinum SDI & 0.51 & 0.51 & 0.52 & 0.54 & 0.54 & 0.56 & 0.56 & 0.55 & 0.55 & 0.56 \\
Other NW areas & 0.46 & 0.46 & 0.46 & 0.48 & 0.49 & 0.50 & 0.50 & 0.49 & 0.49 & 0.50 \\
\hline
\end{tabular}

Source: Global Insight, 2010-Rex Database (Authors'own calculations)

TABLE 1 considers the Human Development Indices over the past 10 years. The HDI figures of the Platinum SDI are only marginally higher than during the initiation of the SDI in 1996. Human development did not grow disproportionably more than the rest of the province, and the coefficient of correlation equals 0.995 , which indicates that there was no significant difference in the basic trend of human development between the Platinum SDI and the rest of the province (Keller, 2001:568). 


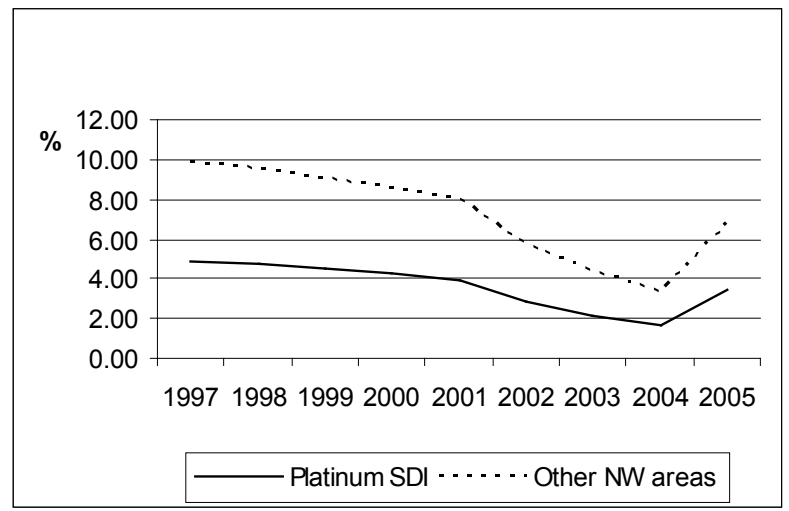

\section{FIGURE 1: Employment Growth Rates}

Source: Adapted from Global Insight, 2010-Rex Database (Authors'own calculations)

Total value added between the regions grew slightly more in the Platinum SDI, but when a correlation matrix is estimated, it yields a correlation of 0.983 , which means there were no significant differences in the general trend and volume. When considering the data, it is not easy to find any proof that the SDI initiatives had any significant effect. This, however, merits a separate investigation and was not the sole objective of this evaluation. It should be admitted that this empirical analysis only served to make a point and is very limited. A meaningful empirical analysis will require a much more detailed analysis and is an important topic for further research.

SDIs and IDZs have become government's policy response to the spatial economic development challenges of South Africa. In the North West Province, large sections are still underdeveloped, with people living in poverty. The earlier article by Kleynhans et al. (2003:628) indicated the necessity of SDIs and IDZ as spatial economic development policy instruments to succeed, where the former RIDPs could not.

This implies that the province has the potential for development, but 10 years have elapsed since the SDI's start in 1996 and very little success due to the SDI programme can be seen. At a seminar in 2001, the provincial governments reaffirmed their commitment to the success of the Platinum SDI, but very little development has followed. New businesses that were established in the area were not more than the natural growth that would have occurred without the Initiative.

\section{CONCLUSION}

This article evaluated the Platinum Spatial Development Initiative (SDI) in the North West Province and its successes and failures over the past 10 years. It also commented on an article concerning the Platinum Spatial Development Initiative that was published by Development Southern Africa during 2003. That article praised the astounding potential of the SDI, the excellent leadership of the authority and their policy framework. The Platinum SDI was established in 1996.

It is now more than 10 years later, and much was spent on research and planning, but there is still very little tangible to show: the Platinum SDI has not significantly improved development in 
the province, nor has it increased the level of human development of its residents. So far, one cannot help but conclude that the Platinum SDI is little more than an "impossible dream".

The earlier article by Kleynhans et al. (2003) did not give that impression. It can now be argued that they did not consider all the facts, and also applied historical facts liberally and selectively - having an unwarranted high esteem of the provincial government. That article was to some extent an unscientific evaluation. The authors seemed biased and refrained from negative criticism. This paper has attempted to rectify these shortcomings.

This commentary firstly considered the historical context and then evaluated some of the arguments that supported and rejected the merits of the Platinum SDI. The historical evolution of the import substitution programme until the acceptance and eventual implementation of an export-promoting focus of the authorities was traced first, followed by the development of regional industrial policy in South Africa. As South Africa is subject to significant spatial inequalities, it has been presumed that the policies introduced to address the spatial inequalities seemingly caused the inequality (Kleynhans et al., 2003:628). It was pointed out above that there are several similarities between the SDI and earlier strategies, and this probably also contributed to the failure of the SDIs thus far. Some of the contributing factors were, for instance, capacity problems, weak implementation and some policy confusion.

It was shown that the objectives of the 1960 decentralisation policy and the 1982 RIDP were to create employment near people's homes, curbing natural urbanisation. These were development objectives, but likewise served political objectives at that time. As these objectives did not succeed, the 1991 RIDP decided to develop areas on "pure economic grounds". Labour was then regarded in the same way as any other input factor of production and assumed to migrate spontaneously to those growth points.

It has been said that the SDI strategy differs from previous strategies, such as the RIDP, in that it follows a multi-sectoral approach, entrepreneurs are not forced to settle in a particular place, and freedom of location exists (Kleynhans et al., 2003). However, what was overlooked was that SDI policy, although considering economic viability, likewise focused on balanced development, implying rural development to a large extent. What the objectives of SDI and the 1960 and 1982 policies have in common are their emphasis on the creation of economic activity and employment near the places where people live. In this respect, SDIs can be seen as a movement back to past policies.

It can be argued that the Platinum SDI seems to have the potential to achieve its growth targets of the province and its manufacturing sector in particular (IDC, 1998:28), but after 10 years there is little evidence that the Platinum SDI will in the near future be efficient. Successful development requires a well-defined and functioning institutional and bureaucratic framework, and the Platinum SDI seems to hinge on adequate institutional support and coordination (Kleynhans et al., 2003:629). Improved institutional arrangements are therefore indispensable. Marketing the Platinum SDI is essential, but the capacity of the provincial government to provide leadership in the development of the Platinum SDI is relatively weak. Invest North West has done excellent work in this regard, but the situation has not improved much up to 2007.

Projects of the Platinum SDI were chosen after a thorough study of the region's potential as well as national and international circumstances, forward and backward linkages and trends (Service Group, 1997:12 \& IDC, 1998a:16). After considering the criteria and criticism of the number of growth points, the principle and location of axes and growth points, the multi-sector approach, the balanced growth endeavour, incentives, research, the freedom to settle, and the 
freedom of mobility of labour and other production factors, it seems that economic development through the Platinum SDI has some potential. Currently, the Platinum SDI has, however, very little to offer and requires a lot more effort by all concerned and much more commitment from the relevant government structures to succeed.

\section{REFERENCES}

Anon. (2006). Mbendi Directory of Organisations. http://www. mbendi.co.za/ orgs/ =cz5f.htm. (Accessed 5 September 2007)

Armstrong, H. \& Taylor, J. (2001). Regional Economics and Policy. Oxford: Blackwell.

Batchelor, P. \& Dunne, P. (1998). The Restructuring of South Africa's Defence Industry. Paper delivered at the Annual Forum of the Trade and Industrial Policy Secretariat, Muldersdrift, 20-22 September 1998.

Belli, P., Finger, M. \& Ballivian, A. (1993). South Africa: Review of Trade Policy Issues, Informal Discussion Papers on Aspects of the Economy of South Africa. Washington: World Bank.

Bos, D.J. (1987). Die Ruimtelik-Ekonomiese Implikasies van Nywerheidsontwikkeling en Desentralisasie as 'n deel van Geïntegreerde Streeksontwikkelingsbeleid vir Suid-Afrika. Unpublished M.Com dissertation. Potchefstroom: Potchefstroom University for Christian Higher Education.

Coetzee, R. \& Joubert, R. (1998). Provincial Sectoral Prospects. Forecasts with the IDC-DGEM. Paper delivered at the Annual Forum of the Trade and Industrial Policy Secretariat, Muldersdrift, 20-22 September 1998.

Coetzee, R., Gwarade, K., Naudé, W. \& Joubert, R. (1997). Currency Depreciation, Trade Liberalisation and Economic Development. South African Journal of Economics, 65(2), pp. 165-190.

Department of Trade and Industry (DTI). (1998). Industrial Policy and Programmes in South Africa. Discussion document. Compiled by the IDC for the DTI. Apr. 1998.

Department of Transport. (1997). Annual Report 1996-1997. Pretoria: Department of Transport.

Department of Transport. (1998). Annual Report 1997-1998. Pretoria: Department of Transport.

Drewes, J.દ. (2009). The Influence of Differential Urbanisation on Regional Policy. Köln, Germany: Lambert Academic Publishing.

Drewes, J.E. \& Bos, D.J. (1995). The Regional Industrial Development Programme, An Evaluation. South African Journal of Economics, 63(2), pp. 247-271.

Dunne, P., Batchelor, P. \& Lamb, G. (1998). The Demand for Military Spending in South Africa.

Discussion paper series: Economics, 4. Centre for Conflict Resolution. Middlesex: Middlesex University Business School.

Geyer, H.S. (1998). The Settlement Strategy of the North West 1998. Research report for Afro Enterprises. University of Potchefstroom: Department of Urban and Regional Planning.

Global Insight (Southern Africa). (2010). REX DATA Base. Available from:

http://www.globalinsight.co.za/. (Accessed 8 September 2010)

Hirsch, A. \& Hanival, S. (1998). Industrial Restructuring in South Africa: The Perspective from Government. Paper delivered at the Annual Forum of the Trade and Industrial Policy Secretariat, Muldersdrift, 20-22 September 2009. 
Horn, A. (1998). Starting all over again. The South African Report. 1998, (1), pp. 40-42.

Industrial Development Corporation (IDC). (1998a). The Platinum Spatial Development Initiative: Scope for Industrial Development. Report compiled by Platinum Consortium and Potchefstroom University. Sandton: Industrial Development Corporation.

Industrial Development Corporation (IDC). (1998b). Gauteng-North West Spatial Development Initiative (SDI): Socio-Economic Analysis of the SDI Area. Report compiled by Potchefstroom University: School of Economics, Money and Banking. Sandton: Industrial Development Corporation.

Industrial Development Corporation (IDC). (1998c). Sectoral Prospects: Growth Guidelines for South Africa's 80 Industries, 1997-2001. Sandton: Industrial Development Corporation.

Keller, G. (2001). Applied Statistics with Microsoft Excel. Pacific Grove: Duxbury/Thomson.

Kleynhans, E.P.J. (2009). A Shift-Share Analysis of Job Creation by the Platinum SDI during its first decade (1996-2006). Paper presented at the $68^{\text {th }}$ International Atlantic Economic Conference, Boston, USA, 8-11 0ctober 2009.

Kleynhans, દ.P.J. (2003). The Competitive Platform for Industrial Development in South Africa. Unpublished PhD thesis. Potchefstroom: Potchefstroom University for Christian Higher Education.

Kleynhans, E.P.J. \& Drewes, J.E. (2008a). The Influence of Location on the Competitiveness of South African Industries. Journal of Economic and Financial Sciences, 2(2), pp.139-158.

Kleynhans, દ.P.J. \& Drewes, J.E. (2008b). The Influence of Location on the Efficiency of Manufacturers in South Africa. Town and Regional Planning, 53, pp.1-8.

Kleynhans, E.P.J., Naudé, W.A. \& Suleman, A. (1998). Regional Industrialisation in South Africa with Special Reference to the Platinum Spatial Development Initiative. Paper delivered at the Annual Forum of the Trade and Industrial Policy Secretariat, Muldersdrift.

Kleynhans, E.P.J., Naudé, W.A. \& Van der Merwe, S.J. (2003). Spatial Economic Development in South Africa: An Overview and Evaluation of the Platinum Spatial Development Initiative. Development Southern Africa, 20(5), pp. 617-631.

Koch, દ., De Beer, G. \& Elliffe, S. 1998. International Perspectives on Tourism-led Development, Some Lessons for the SDIs. Development Southern Africa. 15(5), pp. 907-915.

Le Roux, $\varepsilon$, (1996). Regional Industrial Development in South Africa- ...from past to present.... Unpublished paper. Vanderbijlpark: Potchefstroom University.

Lewis, D. \& Bloch, R. 1998. SDIs: Infrastructure, Agglomeration and the Region in Industrial Policy. Development Southern Africa, 15(5), pp. 727-755.

Ligthelm, A.A. \& Wilsenach, A. (1993). A Preliminary Evaluation of the New RIDP and its Impact on Regional Development in South Africa. Development Southern Africa, 10(3), pp. 361-381.

Mafikeng Industrial Development Zone (MIDZ). (2006). http://www.midz.co.za. (Accessed l October 2007)

Maxim Planning Solutions. (2004). North West Provincial Spatial Development Strategy. Mafikeng.

Michell, J. (1998). SDIs: Infrastructure, Agglomeration and the Region in Industrial Policy. Development Southern Africa. 15(5), pp. 757-769.

Modiselle, M. (2001). Annual Budget Speech by the MEC for Economic Development and Tourism. Mafikeng: North West Provincial Legislature. 
Morule, P.M.H. (2001). North West Spatial Development Initiatives. Presentation delivered at the North West Spatial Development seminar. Mmabatho: North West Provincial Government.

Naudé, W.A. (1999). Economic Development Concepts and Issues in South Africa. Potchefstroom: Potchefstroom University. Telematic Learning Systems.

Naudé, W.A. \& Krugell, W.F. (2003). Are South Africa's Cities Too Small? Cities, 20(3), pp. 175-180.

North West Province. (2001). Government Financial Statistics System. Revenue: An Estimates of Expenditure for the Year Ending 31 March 2002. Mafikeng: North West Provincial Legislature.

Panel of Experts. (1989). Evaluation of the Regional Industrial Development Program as an Element of the Regional Development Policy in South Africa. Midrand: Development Bank of Southern Africa.

Republic of South Africa. (1991). National Regional Development Program: General Overview, Vol.1. Office for Regional Development and Regional Development Advisory Committees. Pretoria: Government Printer.

Ryan, C. (1998). One for the Record Book. The South Africa Report, 1, pp. 30-38

Services Group Inc. (1997). North West Province Investor Targeting Strategy. Draft Report. May 1996.

Strategic Planning and Development Unit. (1997). North West 2001. Mmabatho: North West Provincial Government.

Suleman, A. (1998). The Competitiveness and Comparative Advantages of South Africa's Manufacturing Sector with Reference to the Provinces. Unpublished PhD Thesis. Potchefstroom: Potchefstroom University for Christian Higher Education.

Van Jaarsveld, F.A. \& Scholtz, G.D. (red.) (1966). Die Republiek van Suid-Afrika. Agtergrond, Ontstaan en Toekoms. Johannesburg: Voortrekkerpers.

Wiese, H. (1996). Regional Industrial Development Strategies: A Comparison of South African Countries. Paper delivered at the EBM Research Conference. 27-28 Nov. 1996. University of Port Elizabeth. 
RE-EVALUATION OF THE PLATINUM SDI: A CRITICAL COMMENTARY 